\title{
Effect of subclinical intramammary infection on somatic cell counts, NAGase activity and gross composition of goats' milk
}

\author{
Gabriel Leitner ${ }^{*}$, Uzi Merin ${ }^{2}$, Nissim Silanikove ${ }^{3}$, Efraim Ezra ${ }^{4}$, Marcelo Chaffer ${ }^{1}$, Natan Gollop ${ }^{2}$, \\ Marta Winkler ${ }^{1}$, Anita Glickman ${ }^{1}$ and Arthur Saran ${ }^{1}$ \\ ${ }^{1}$ National Mastitis Reference Centre, Kimron Veterinary Institute, Israel \\ ${ }^{2}$ Department of Food Science, Institute of Technology and Storage of Agricultural Products \\ ${ }^{3}$ Department of Animal Physiology, Institute of Animal Science, Agricultural Research Organization, The Volcani Centre, Israel \\ ${ }^{4}$ Israel Cattle Breeders Association, Caesarea, Israel
}

Received 7 February 2003 and accepted for publication 20 August 2003

\begin{abstract}
The study was aimed at identifying the pathogens causing subclinical udder infections in representative Israeli dairy goat herds and determining their effect on milk quality. Five hundred goats in ten flocks of various breeds and crossbreeds were surveyed. Of the 500 goats, $13.4 \%$ were in their first lactation, 36.4\% were in their second lactation and $50 \cdot 2 \%$ were in their third or higher lactation. Percentages of udder halves with subclinical intramammary infection in the flocks ranged from 35 to $71 \%$. The effect of the bacteriological infection on somatic cells count (SCC) was significant $(P<0 \cdot 001)$. Various species of coagulase-negative staphylococci (CNS), mainly Staphylococcus caprae and Staphylococcus epidermidis, were the main pathogens in infected udder halves. Lactation number did not significantly influence either infection rate of udder halves or SCC, although the percentage of udder halves with no bacteriological findings was higher at the first lactation than at the third lactation. Milk composition (fat, protein and lactose) varied among flocks, with lower mean total protein in uninfected halves than in infected ones and higher lactose in uninfected than infected halves.
\end{abstract}

Keywords: Subclinical mastitis, milk composition, goat.

Intramammary infection (IMI) raises milk somatic cell count (SCC) and reduces milk yield and milk quality in dairy cows (Harmon, 1994) and sheep (Watson \& Buswell, 1984), but in goats this interrelationship is less clear (Haenlein \& Hinckley, 1995; Sanchez et al. 2002). In goats, involution tends to be spontaneous and is associated with an increase of SCC independently of IMI, which confounds the interrelationship between IMI and milk yield (Wilson et al. 1995; Zeng \& Escobar, 1996; Foschino et al. 2002).

In goats, possible limitations of bacteriological analyses as gold standard in mastitis diagnosis cannot be met by the indirect tests proposed, such as SCC, California mastitis test (CMT) or $\mathrm{N}$-acetyl- $\beta$-D-glucosaminidase (NAGase) activity. The validity of these tests in goat milk is not clear and further studies are needed for different goat breeds and systems of production. In cows, SCC is an indicator of normal or abnormal milk while, for goat milk, it is

*For correspondence; e-mail : leitnerg@int.gov.il inappropriate because of the presence of many cytoplasmic particles resulting from apocrine milk secretion (Maisi, 1990; Atherton, 1992). However, Fossomatic calibrated with goat milk, CMT or even Coulter Counter, after applying an appropriate correction factor, could be used as indirect tests (Heanlein, 2002). In dairy cows (Chaffer et al. 1999; Leitner et al. 2001) and dairy sheep (Leitner et al. 2003) the changes accruing throughout lactation in the bacteriological status of a mammary gland (quarter or half) are minimal with a high correlation between the pathogens identified, SCC and NAGase activity. These results indicate that testing cows and sheep once in mid lactation gives a good indication of bacteriological status of the udder. In goats, indirect tests are questionable if carried out shortly after kidding and towards the end of lactation.

The present study was aimed at identifying the pathogens causing subclinical udder infections in representative Israeli dairy goat herds asnd determining their influence on milk quality. This was done by single sampling of milk of individual udder halves between 25 and $130 \mathrm{~d}$ post partum. 


\section{Materials and Methods}

\section{Animals}

Ten Israeli dairy goat herds representing various breeds (Saanen, Shami) and crossbreeds (Shami $\times$ Anglo Nubian, Saanen $\times$ Anglo Nubian), from different locations, size of herd (150-800 goats) and lactation number (1-9) were surveyed. From each herd, 50 goats were randomly chosen from the pool of goats that were at least $25 \mathrm{~d}$ and not more than $130 \mathrm{~d}$ after kidding. Annual lactation milk yield of these herds ranged from 350 to $1200 \mathrm{l} /$ goat and the daily yield ranged from 0.5 to $6 \mathrm{l} / \mathrm{d}$. Under Israeli goat herd management, the kids are removed immediately after birth and goats are milked with milking machine twice a day with teat post-dipping only. At drying-off, no treatment is applied. Food is usually offered in mangers in free stall barns.

\section{Milk sampling}

In each goat, udder halves were sampled and tested for udder bacterial condition, SCC, NAGase activity and the concentrations of fat, protein and lactose in milk were measured. Udder halves were sampled during the morning or evening milking. Teats were cleaned and disinfected before sampling with non-woven towelets moistened with chlorhexidine, cetrimide and ethanol (MediWipes, Al-Baad, Massuot Itzhak, Israel). The first few squirts of milk were discarded and $\sim 5 \mathrm{ml}$ was then taken into a sterile tube for bacteriological testing and NAGase activity. Samples were taken aseptically according to International Dairy Federation (IDF) procedures (1985) and kept at $4-8{ }^{\circ} \mathrm{C}$ until tested at the laboratory $1-5 \mathrm{~h}$ later. SCC and milk composition were determined according to the revised protocol of the A2B sub-group of mastitis experts (IDF, 1991). Foremilk $(50 \mathrm{ml})$ was taken from each half to determine SCC with a Fossomatic 360 and milk composition with a Milkoscan 6000 (Foss Electric, Hillerød, Denmark), both calibrated with goat milk, at the Milk Control Laboratory, Israel Cattle Breeders Association, Caesarea, Israel.

\section{Bacteriological procedure}

Bacteriological examination was according to accepted standards (Hogan et al. 1999): 0.01 ml of each milk sample was spread onto blood-agar plates (Bacto-Agar, Difco Laboratory) containing $5 \%$ of washed sheep red blood cells and on MacConkey plates. All plates were incubated at $37{ }^{\circ} \mathrm{C}$ and examined for growth at 18 and $42 \mathrm{~h}$. Colonies suspected of being staphylococci were tested for coagulase (tube test, Anilab, Rehovot, Israel). Strain identification was carried out with the API STAPH-IDENT, 32 Staph kit (bioMerieux S.A., 69280 Marcy-I'Etoile, France). When the percentage of micrococci-like bacteria that matched the test strain was $>90 \%$, the strain was regarded as specific. If the percentage was $<90 \%$, the strain was registered as unidentified coagulase-negative staphylococci (CNS).
Table 1. Distribution of the 500 various breeds and crossbreeds of dairy goatsused in the experiment, according to flock, lactation number and average $( \pm \mathrm{SD})$ days in milk (DIM)

\begin{tabular}{crrrc} 
& \multicolumn{3}{c}{ Lactation } \\
\cline { 2 - 3 } Flock & 1 & 2 & $>3$ & DIM+ \\
1 & 2 & 36 & 12 & $95 \pm 50$ \\
2 & 2 & 8 & 40 & $31 \pm 5$ \\
3 & 2 & 24 & 24 & - \\
4 & 6 & 18 & 26 & - \\
5 & 6 & 13 & 31 & - \\
6 & 2 & 26 & 22 & $104 \pm 114$ \\
7 & 12 & 13 & 25 & $77 \pm 17$ \\
8 & 3 & 9 & 38 & - \\
9 & 15 & 20 & 15 & $50 \pm 2$ \\
10 & 17 & 15 & 18 & $105 \pm 92$ \\
Total & 67 & 182 & 251 & \\
† Four goat herds did not record DIM &
\end{tabular}

Table 2. Mean and SE of NAGase activity and somatic cell count (SCC) by Fossomatic 360 and the effects of udder bacteriological status and flock, lactation number and days in milk for six goat herds

$\begin{array}{llcl}\text { Status } & \text { NAGase } & \text { SCC } \times 10^{-3} & \log \text { SCC } \\ \text { Uninfected }(n=327) & 15 \cdot 6 \pm 0 \cdot 8 & 338 \pm 29 \cdot 0 & 5 \cdot 12+0 \cdot 07 \\ \text { Infected }(n=273) & 59 \cdot 2 \pm 5 \cdot 3 & 1922 \pm 109 \cdot 8 & 6 \cdot 83+0 \cdot 08 \\ \begin{array}{llll}\text { Statistical significance } \\ \text { of effects of: }\end{array} & & & \\ \quad \text { Bacteriological status } & <0 \cdot 001 & <0 \cdot 001 & <0 \cdot 001 \\ \text { Flock } & <0 \cdot 01 & <0 \cdot 01 & <0 \cdot 01 \\ \text { Lactation } & \text { NS } & \text { NS } & \text { NS } \\ \text { Days in milk } & \text { NS } & \text { NS } & \text { NS }\end{array}$

Gram-negative colonies were identified with the API $20 \mathrm{E}$ or API NE kit (bioMerieux S.A., 69280 Marcy-I'Etoile, France).

\section{NAGase test}

Concentrations of NAGase were determined fluorimetrically according to the ADL MILK NAGase test kit (Applied Diagnostics Corporation, Helsinki, Finland) with a computerized microplate setting. A value of 100 corresponds to the release of substrate-derived product at $5 \mu \mathrm{mol} \mathrm{I}{ }^{-1} \mathrm{~min}^{-1}$ at $25{ }^{\circ} \mathrm{C}$.

\section{Statistical analysis}

Results were analysed with the SAS General Linear Model procedure (SAS/STAT ${ }^{\circledR}$ User's Guide, 1990). No differences were found in the arithmetic means of IMI parameter and milk composition between all the herds and the six goat herds that had a complete dataset. Therefore, statistical analysis was done only on the six goat herds that had recorded days in milk (DIM). Dependent variables 
Table 3. Distribution of 500 dairy goat udders (1000 halves) from 10 different flocks, according to udder bacteriology infection and SCC measured with Fossomatic 360

\begin{tabular}{|c|c|c|c|c|}
\hline Bacteria & $\begin{array}{l}\text { Number of } \\
\text { udder halves } \\
\text { infected }\end{array}$ & $\begin{array}{l}\text { Number } \\
\text { of flocks }\end{array}$ & $\mathrm{SCC} \times 10^{-3} \pm \mathrm{SE}$ & $\log \mathrm{SCC} \pm \mathrm{SE}$ \\
\hline Staph. aureus & 38 & 8 & $3593 \pm 259$ & $6 \cdot 49 \pm 0 \cdot 04$ \\
\hline \multicolumn{5}{|l|}{ CNS: } \\
\hline Staph. caprae & 167 & 10 & $1426 \pm 205$ & $5 \cdot 93 \pm 0 \cdot 04$ \\
\hline Staph. chromogenes & 41 & 8 & $1744 \pm 236$ & $6 \cdot 06 \pm 0 \cdot 07$ \\
\hline Staph. epidermidis & 95 & 10 & $1529 \pm 208$ & $6 \cdot 02 \pm 0 \cdot 04$ \\
\hline Staph. simulans & 66 & 10 & $1996 \pm 182$ & $6 \cdot 16 \pm 0 \cdot 05$ \\
\hline Staph. xylosos & 13 & 4 & $791 \pm 192$ & $5 \cdot 8 \pm 0 \cdot 08$ \\
\hline Non-identified CNS & 53 & 8 & $1189 \pm 205$ & $5 \cdot 63 \pm 0 \cdot 1$ \\
\hline Total CNS & 435 & 10 & $1676 \pm 74$ & $5 \cdot 99 \pm 0 \cdot 02$ \\
\hline Other \& not identified & 39 & 9 & & \\
\hline Total uninfectedt & $488(48 \%)$ & & $288 \pm 21 \cdot 1$ & $5 \cdot 19 \pm 0 \cdot 02$ \\
\hline Total infected & $512(52 \%)$ & & $1626 \pm 70 \cdot 8$ & $6 \cdot 00 \pm 0 \cdot 02$ \\
\hline
\end{tabular}

+ Uninfected halves, no bacterial growth on blood-agar and MacConkey plates

were: SCC and Log SCC, NAGase, fat, protein and lactose. The independent variables (bacteriological status, flock, lactation number and DIM) were examined according to the model:

$Y_{i j k}=\mu+B_{i}+H_{j}+L_{k}+D_{1} M_{i j k}+e_{i j k}$

where: $Y=$ dependent variable; $\mu=$ overall mean; $B=$ bacteriological status $\mathrm{I}=1,2 ; \mathrm{H}=$ flock, $\mathrm{J}=1,6 ; \mathrm{L}=$ lactation number, $k=1,2,3+$; DIM is a continuous variable; $e=$ error.

No significant difference was found between morning and evening milk sampling and because most herds (8 out of 10) were sampled in the morning, this variable was excluded from the model. No significant difference was found between analyses based on SCC and those based on $\log$ SCC.

\section{Results}

Table 1 shows the distribution of the 500 surveyed goats according to flock, lactation number and average DIM. Of the 500 goats, $13 \cdot 4 \%(67 / 500)$ were in their first lactation, $36.4 \%(182 / 500)$ were in their second lactation and $50 \cdot 2 \%(251 / 500)$ were in their third or higher lactation. The percentage of bacteriologically infected udder halves in the flocks ranged from 35 to $71 \%$. Although the percentage of uninfected udder halves was numerically higher for first and second lactations than for third lactation (54, 56 and $31 \%$, respectively) the difference was not statistically significant. The correlation between SCC and NAGase activity was low $(R<0 \cdot 7)$. No interaction was found between bacteriological status and flock in its effect on SCC or NAGase activity. Bacteriological status (infected or uninfected half) significantly affected both NAGase and SCC $(P<0 \cdot 001)$. Flock effect was significant for NAGase, SCC and log SCC $(P<0 \cdot 01)$ (Table 2). Effects of lactation number and DIM on SCC were not significant.

No bacterial growth was detected in the milk of $48 \%$ of halves (488/1000) and those were classified as uninfected.
Staphylococcus aureus was detected in eight flocks, in only one to six goats per flock, and caused marked increases in SCC, to $>3 \times 10^{6}$ cells $/ \mathrm{ml}$ (Table 3 ). Various species of CNS formed the main pathogenic group in infected udders and for the majority of the CNS species; infection of one half did not affect the other. Staphylococcus caprae and Staphylococcus epidermidis accounted for most CNS and they were found in all the flocks tested (Table 3). Other major CNS were Staphylococcus chromogenes and Staphylococcus simulans. The presence of CNS elicited strong inflammatory responses, increasing SCC to $10^{6}$ cells $/ \mathrm{ml}$ with no significant difference among the various strains (Table 3). Statistical analysis of each of the five CNS species in the model showed no significant effects for all the dependent variables.

Milk fat, protein and lactose concentrations ranged among flocks from $19 \cdot 9$ to $55 \cdot 6 \mathrm{~g} / \mathrm{l}$ for fat, $34 \cdot 0$ to $51 \cdot 1 \mathrm{~g} / \mathrm{l}$ for total protein and $47 \cdot 4$ to $51 \cdot 1 \mathrm{~g} / \mathrm{l}$ for lactose. Statistical analysis for the six goat herds that were included in the model showed that the mean total protein and fat were lower in uninfected halves than that in infected ones (39.1 v. $39.9 \mathrm{~g} / \mathrm{l}$ for protein and $37.5 \mathrm{v} .42 \cdot 0 \mathrm{~g} / \mathrm{l}$ for fat), whereas lactose was higher in uninfected than in infected halves $(49.6$ v. $47 \cdot 2 \mathrm{~g} / \mathrm{l})$. Effects of bacteriological status (infected or uninfected) for the six goat herds were not significant for fat but significant $(P<0.01$ and $<0.001)$ for protein and lactose, respectively (Table 4$)$. Flock effect on all of the parameters was significant $(P<0 \cdot 001)$ whereas effect of lactation number was significant for protein and lactose but not for fat, and effect of DIM was significant for fat and protein but not for lactose (Table 4).

\section{Discussion}

CNS, mainly Staph. caprae, Staph. epidermidis, Staph. chromogenes and Staph. simulans, were the most abundant bacterial isolates, and were found in almost all flocks tested. Escherichia coli, Staph. aureus, streptococci and 
Table 4. Mean values and SE for milk fat, protein, and lactose according to udder-half bacteriological status in six goat herds, and the effects of udder bacteriological status, flock, lactation number, time of milking and days in milk

\begin{tabular}{|c|c|c|c|}
\hline Status & Fat, $g / l$ & Protein, g/l & Lactose, \\
\hline Uninfected $(n=327)$ & $37 \cdot 5 \pm 0 \cdot 09$ & $39 \cdot 1 \pm 0 \cdot 03$ & $49 \cdot 6 \pm 0 \cdot($ \\
\hline Infected $(n=273)$ & $42 \cdot 0 \pm 0 \cdot 09$ & $39 \cdot 9 \pm 0 \cdot 03$ & $47 \cdot 2 \pm 0 \cdot($ \\
\hline \multicolumn{4}{|l|}{$\begin{array}{l}\text { Statistical significance } \\
\text { of effects of: }\end{array}$} \\
\hline Bacteriological status & NS & $<0.001$ & $<0 \cdot 001$ \\
\hline Flock & $<0.001$ & $<0.001$ & $<0 \cdot 001$ \\
\hline Lactation & NS & $<0.001$ & $<0.001$ \\
\hline Days in milk & $<0.001$ & $<0.001$ & NS \\
\hline
\end{tabular}

Pseudomonas spp. are commonly isolated from cases of clinical mastitis (Menzies \& Ramanoon, 2001) and hence the numbers of goats that were found to be infected with these bacteria in the present study did not reflect their frequencies in the flocks. Moreover, in the last 5 years, sheep and goat flocks in Israel have suffered outbreaks of mastitis caused by Pseudomonas aeruginosa (Rapoport et al. 1998) and those with acute clinical symptoms were removed from the flocks.

All CNS isolates in this study similarly affected the mammary glands, as indicated by SCC, which increased above $1000 \times 10^{3}$ cells $/ \mathrm{ml}$. This trend is discussed by Haenlein (2002), who reports over $10^{6}$ cells $/ \mathrm{ml}$ in response to CNS IMI in different countries. Other factors such as lactation, DIM and caprine arthritis-encephalitis virus infection are associated with increased SCC in goats (Ryan et al. 1993; Haenlein \& Hinckley, 1995; Wilson et al. 1995). However, avoiding sampling goats immediately after parturition and not more than $130 \mathrm{~d}$ after kidding reduced the contribution of lactation number and DIM in the present work and strongly suggested that increased SCC is associated with IMI during this period. Therefore, it is strongly suggested that within the limit of the above period, SCC or NAGase activity should be complemented with bacterial testing to assess IMI. Moreover, since in Israel most of the milk is yielded during this period (25-130 d), the increase in SCC regardless of IMI towards the end of lactation has less effect on bulk milk SCC. A similar association between infection with CNS and high level of SCC occurs in sheep (Fthenakis, 1994; GonzalezRodriguez et al. 1995; Las Heras et al. 1999; Leitner et al. 2001), indicating that the immune response in sheep and goats is more acute than in cows, although normal SCC in goat and sheep is higher than for cows (Paape \& Capuco, 1997).

IMI, even if only subclinical, decreases milk yield in

TQ1 sheep (McCarthy et al. 1988; Fthenakis \& Jones, 1991; Leitner et al. 2003). A basic feature of mammary secretion is that the total osmotic pressure of the secretion is approximately constant and equal to that of blood (Holt, 1993). As lactose is the main osmotic component in milk, the secretion volume closely follows changes in the secretion of lactose (Shamay et al. 2000). Thus, based on the decrease in lactose concentration in the infected glands, it is assumed that subclinical mastitis is associated with reduced milk yield also in goats. The decrease in lactose concentration in the infected halves is consistent with similar findings in sheep (Burriel, 1997; Leitner et al. 2003). However, it remains unclear whether the decrease in lactose concentration is related to microbial activity or to the effect of plasmin-induced casein-derived products on mammary epithelial cells (Shamay et al. 2002, 2003).

The milk from 6 of the 10 farms in the present study is processed by the owners into fermented milk products and cheese, so any changes in the dry matter, mainly casein concentration, have economic impact. In the present study, levels of fat and total protein were significantly higher in the infected halves than in the uninfected ones, consistent with recent findings in sheep (Leitner et al. 2003). In dairy cows, milk with high SCC shows an extended coagulation time and forms a weak coagulum (Auldist et al. 1996), so that the cheese is higher in moisture and dry matter yield is reduced. Milk from a mastitic cow's udder has increased proteolytic activity and is associated with a reduced concentration of caseins and an increased concentration of whey protein (Schaar \& Funke, 1986). Therefore, measurements of casein yield, casein proportions and curd yield and parameters reflecting cheese quality are essential to assess the effect of subclinical mastitis on cheese yield and quality in goats.

This work was partly supported by grant from MERC, Middle East Research and Cooperation fund, Project No. M18-001. The technical assistance of A Agbar, D Cababia and Y Carraso of the Extension Service of the Israel Ministry of Agriculture is greatly appreciated.

\section{References}

Atherton HV 1992 Using somatic cells and antibiotic test for determining the quality of goat milk. In Proceeding of the National Symposium on Dairy Goat Production and Marketing, pp. 128-135 (Eds TA Gipson, SP Hart \& LT Trung). Langston, OK, USA: Langston University

Auldist MJ, Coats S, Sutherland JB, Mayes JJ \& McDowell HG 1996 Effects of somatic cell count and stage of lactation on raw milk composition and the yield and quality of cheddar cheese. Journal of Dairy Research 63 269-280

Burriel AR 1997 Dynamics of intramammary infection in sheep caused by coagulase-negative staphylococci and its influence on udder tissue and milk composition. Veterinary Record 140 419-423

Chaffer M, Leitner G, Winkler M, Glickman A, Krifucks O, Ezra E \& Saran A 1999 Coagulase-negative Staphylococci and mammary gland infections in cows. Journal of Veterinary Medicine B 46 707-712

Foschino R, Invernizzi A, Barruco R \& Straditto K 2002 Microbial composition, including the incidence of pathogens, of goat milk from the Bergamo region of Italy during a lactation year. Journal of Dairy Research $69213-225$

Fthenakis GC 1994 Prevalence and aetiology of subclinical mastitis in ewes of Southern Greece. Small Ruminant Research 13 293-300

Fthenakis GC \& Jones JET 1990 The effect of experimentally induced subclinical mastitis on milk yield of ewes and on the growth of lambs. British Veterinary Journal 146 43-49 


\section{Subclinical intramammary infection}

Gonzalez-Rodriguez CM, Gonzalo C, Primitivo FS \& Carmenes P 1995 Relationship between somatic cell count and intramammary infection of the half udder in dairy ewes. Journal of Dairy Science 78 2753-2759

Haenlein GW 2002 Relationship of somatic cell counts in goat milk to mastitis and productivity. Small Ruminant Research 45 163-178

Haenlein GW \& Hinckley LS 1995 Goat milk somatic cell count situation in USA. International Journal of Animal Science 10 305-310

Harmon RJ 1994 Physiology of mastitis and factors affecting somatic cell counts. Journal of Dairy Science 77 2103-2112

Hogan SJ, Gonzalez NR, Harmon JR, Nickerson CS, Oliver PS, Pankey JW \& Smith KL 1999 Laboratory Handbook on Bovine Mastitis. Revised Edition. Madison, WI, USA: NMC Inc

Holt C 1993 Interrelationship of the concentrations of some ionic constituents of human milk and comparison with cow and goat milks. Comparative Biochemistry and Physiology 104 35-41

International Dairy Federation 1985 Laboratory methods for use in mastitis work. IDF Document 132, Brussels, Belgium

International Dairy Federation 1991 Milk enumeration of somatic cells. International IDF Standard 148, Brussels, Belgium

Las Heras A, Dominguez L \& Fernandez-Garayzabal JF 1999 Prevalence and aetiology of subclinical mastitis in dairy ewes of the Madrid region. Small Ruminant Research 32 21-29

Leitner G, Chaffer M, Carasso Y, Ezra E, Kababya D, Winkler M, Glickman A \& Saran A 2003 Udder infection and milk somatic cell count, NAGase activity and milk composition - fat, protein and lactose - in Israeli Assaf and Awassi sheep. Small Ruminant Research 49 157-164

Leitner G, Chaffer M, Zamir S, Mor T, Glickman A, Winkler M, Weisblit L \& Saran A 2001 Udder disease aetiology, milk somatic cell count and NAGase activity in Israeli Assaf sheep throughout lactation. Small Ruminant Research 39 107-112

McCarthy FD, Lindsey JB, Gore MT \& Notter DR 1988 Incidence and control of subclinical mastitis in the intensively managed ewes. Journal of Animal Science $\mathbf{6 6} 2715-2721$

Maisi P 1990 Milk NAGase, CMT and antitrypsin as indicators of caprine subclinical mastitis infections. Small Ruminant Research 83 493-501

Menzies IP \& Ramanoon ZS 2001 Mastitis of sheep and goats. Veterinary Clinics of North America: Food Animal Practice 17 333-358
Paape JM \& Capuco VA 1997 Cellular defense mechanism in udder and lactation of goats. Journal of Animal Science 75 556-565

Rapoport E, Vishinsky Y, Hanoch U, Faingold D, Shani A, Gatib N \& Kussak A 1998 Outbreak of acute ovine mastitis caused by Pseudomonas aeruginosa. In Milking and Milk Production of Dairy Sheep and Goats. Proceedings of the Sixth International Symposium on the Milking of Small Ruminants, Athens, Greece

Ryan DP, Greenwood LP \& Nicholoss JP 1993 Effect of caprine arthritisencephalitis virus infection on milk cell count $\mathrm{N}$-acetyl- $\beta$-glycosaminidase activity in dairy goats. Journal of Dairy Research 60 299-306

Sanchez A, Fernandez C, Contreras A, Luengo C \& Rubert J 2002 Effect of intramammary infection by Staphylococcus caprae on somatic cell counts and milk composition in goats. Journal of Dairy Research $\mathbf{6 9}$ $325-328$

SAS 1990 SAS/STAT ${ }^{\circledR}$ User's Guide, Version 6, Fourth Edn, Vol. 2. SAS Inst. Inc., Cary, NC, USA

Schaar J \& Funke H 1986 Effect of subclinical mastitis on milk plasminogen and plasmin compared with that on sodium, antitrypsin and $\mathrm{N}$ acetyl-D-glucosaminidase. Journal of Dairy Research 53 515-528

Shamay A, Shapiro F, Barash H, Bruckental I \& Silanikove N 2000 Effect of dexamethasone on milk yield and composition in dairy cows. Annales de Zootechnie 49 343-352

Shamay A, Shapiro F, Leitner G \& Silanikove N 2003 Infusions of casein hydrolysates into the mammary gland disrupt tight junction integrity and induce involution in cows. Journal of Dairy Science $\mathbf{8 6}$ 1250-1258

Shamay A, Shapiro F, Mabjeesh SJ \& Silanikove N 2002 Casein-derived phosphopeptides disrupt tight junction integrity, and precipitously dry up milk secretion in goats. Life Sciences 70 2707-2719

Watson DJ \& Buswell JF 1984 Modern aspects of sheep mastitis. British Veterinary Journal 140 529-534

Wilson DJ, Stewart KN \& Sears PM 1995 Effect of stage of lactation, parity and season on somatic cell count in infected and uninfected dairy goats. Small Ruminant Research 16 165-169

Zeng SS \& Escobar EN 1996 Effect of breed and milking method on somatic cell count, standard plate count and composition of goat milk. Small Ruminant Research 19 169-175 